\title{
Dinamika Kemandirian Mahasiswa Perantauan
}

\author{
Nadia Fauzia, Asmaran dan Shanty Komalasari \\ Universitas Islam Negeri (UIN) Antasari Banjarmasin
}

\begin{abstract}
The purpose of this study is to discuss the dynamics of the independence of UIN Antasari Banjarmasin students and what factors are behind the independence of UIN Antasari Banjarmasin students. The reason is because overseas there are changes in conditions and situations, so that students who leave will experience dynamics of independence. This type of research is a qualitative descriptive research approach. Selection of subjects using purposive sampling technique, which is based on the characteristics of the subject in accordance with the research objectives to be carried out. The object of this research is the dynamics of independence, the subject is 5 overseas students. Data collection techniques using interviews and observations. Based on the results of research that overseas students of UIN Antasari Banjarmasin need a process to be independent in living their lives overseas. That is because overseas there has been a change. Factors that influence the dynamics of independence of overseas students at UIN Antasari Banjarmasin arefactors of parenting style, the order of children in the family, age and the education system in schools.
\end{abstract}

Keywords: The dynamics of independence; out-town collage student

\begin{abstract}
Abstrak
Tujuan penelitian ini membahas dinamika kemandirian mahasiswa perantauan UIN Antasari Banjarmasin dan faktor apa yang melatarbelakangi kemandirian mahasiswa perantauan UIN Antasari Banjarmasin. Alasanya ialah karena di perantauan terjadi perubahan kondisi maupun situasi, sehingga mahasiswa yang merantau akan mengalami dinamika kemandirian. Jenis penelitian ini adalah pendekatan penelitian deskriptif kualitatif. Pemilihan subjek menggunakan teknik purposive sampling, yaitu berdasarkan ciri dimiliki subjek yang sesuai dengan tujuan penelitian yang ingin dilakukan. Objek penelitian ini adalah dinamika kemandirian, subjeknya mahasiswa perantauan sebanyak 5 orang. Teknik pengumpulan data menggunakan wawancara dan observasi. Berdasarkan hasil penelitian bahwasanya mahasiswa perantauan UIN Antasari Banjarmasin membutuhkan proses untuk bisa mandiri dalam menjalani kehidupan di perantauan. Itu disebabkan di perantauan telah terjadi perubahan. Faktor yang mempengaruhi dinamika kemandiran mahasiswa perantauan UIN Antasari Banjarmasin ialah faktor pola asuh orang tua, urutan anak dalam keluarga, usia dan sistem pendidikan di sekolah.
\end{abstract}

Kata kunci: Dinamika kemandirian; mahasiswa perantauan 
Rantau adalah suatu keadaan yang sudah terjadi sejak dulu dan berlanjut hingga sekarang. Seorang perantauan adalah seseorang yang akan meninggalkan kampung halamannya dengan jangka waktu yang lama. Ada berbagai tujuan yang mendorong seseorang untuk merantau, di antaranya adalah seseorang meninggalkan kampung halaman untuk melanjutkan pendidikannya. Di zaman globalisasi ini juga, tidak sedikit orang yang melanjutkan pendidikannya ke jenjang yang lebih tinggi dengan merantau, diantaranya yaitu seorang mahasiswa. Seorang mahasiswa yang merantau pasti tinggal di luar daerah kampung halamannya dengan waktu tertentu, untuk menyelesaikan pendidikanya atau dengan kata lain mahasiswa merantau. (Halim dan Dariyo 2017). Mahasiswa perantauan ialah seorang mahasiswa yang menempuh pendidikannya dengan merantau. Pastinya akan meninggalkan kampung halamannya dengan menjalani kehidupan sendiri tanpa ada keluarga di sam pingnya. Di tempat perantauan, ketika dihadapi situasi dan kondisi apapun, seorang mahasiswa dituntut untuk bisa menanganinya sendiri. Hal itu dikarenakan di tempat perantauan situasinya berbeda. Peluang untuk bergantung pada orang lain sangatlah minimal dan pemenuhan kebutuhan hidupnya haruslah ditanggulangi sendiri.

Hurlock juga menyatakan bahwa supaya bisa mendapatkan tujuan dari pola sosialisasi dewasa juga diperlukan penyesuaian baru, seperti yang dialami oleh mahasiswa perantauan. Pertama, ketidakhadiran orang tua. Kedua, sistem pertemanan serta komunikasi yang berbeda dengan teman baru. Ketiga, penyesuaian terhadap norma sosialisasi warga setem pat. Terakhir yaitu gaya belajar yang sulit untuk diikuti. Sebab dari itulah yang menyebabkan adanya perubahan situasi kehidupan mahasiswa yang merantau, karena menuntut usaha yang lebih besar. Hal itu dikarekan supaya mahasiswa itu mandiri dalam menghadapi perubahan lingkungan di tempat perantauan. (Lingga 2012). Adapun kemandirian menurut Steinberg secara psikososial tersusun dari tiga aspek. Pertama, kemandirian emosional merupakan kemandirian yang menyatakan adanya perubahan kedekatan hubungan emosional antar orang lain, seperti halnya hubungan emosional dengan orang tuanya atau hubungan dengan orang dewasa lainnya atau orang yang banyak melakukan interaksi dengannya. Kedua, yaitu mandiri bertindak adalah kemampuan seseorang supaya bisa memutuskan sesuatu secara bebas dan menindaklanjutinya serta bertanggung jawab. Terakhir adalah mandiri berfikir, yaitu 
kebebasan untuk memaknai prinsip yang benar dan yang salah, baik dan buruk serta apa yang berguna untuk dirinya. (Nurhayati 2016). Kemandirian juga dijelaskan dalam Q.S. ar-Ra'd/13: 11, yang artinya :

Sesungguhnya Allah tidak merubah keadaan sesuatu kaum sehingga mereka merubah keadaan yang ada pada diri mereka sendiri. (Al-Qurthubi 2009).

Allah Swt tidak akan membebani seseorang dengan kewajiban atau perintah kecuali perintah itu sanggup dilaksanakan oleh hambanya dan dalam batas-batas kemampuannya. Hal itu dikarenakan seseorang dituntut supaya mandiri dalam menyelesaikan persoalannya tanpa terus bergantung kepada orang lain. Kesuksesan seseorang itu tergantung dari usahanya sendiri, yang kemudian dibarengi dengan do'a, serta kesabaran dalam menjalani proses dan perjuangannya. Setiap orang mempunyai tanggung jawab pada setiap apa yang diperbuatnya. Selama hidup di dunia, sesuatu yang dilakukan harus dengan mandiri. Hal itu dikarenakan tidak setiap apa yang dilakukan harus bergantung dengan orang lain. Demikian pula ini adalah merupakan bukti, bahwasanya setiap orang itu mempunyai tanggung jawab supaya melakukan sesuatu itu dengan secara mandiri.

Adapun dalam proses untuk mendapatkan karakter mandiri dapat dipengaruhi oleh beberapa faktor. Seperti menurut Ali dan Asrori bahwasanya ada empat faktor yang mempengaruhi kemandirian. Pertama gen atau keturunan orang tua, Orang tua yang mempunyai sifat kemandirian yang tinggi, seringkali menurunkan anak yang mempunyai kemandirian juga. Akan tetapi faktor keturunan ini juga masih menjadi perdebatan. Hal itu dikarenakan ada yang mengatakan kalau itu bukan sifat kemandirian orang tuanya yang menurun pada anaknya, akan tetapi itu sifat orang tua yang mendidik anaknya. Kedua, pola asuh orang tua. Cara orang tua mendidik anak, bisa mempengaruhi perkembangan kemandirian anaknya. Orang tua yang terlalu sering melarang atau bisa juga mengeluarkan kata "jangan" pada anak dengan tidak disertai penjelasan yang rasioanal, maka itu bisa menghambat perkembangan kemandirian anak. Akan tetapi apabila sebaliknya, orang tua yang menciptakan suasana yang aman dalam interaksi keluarganya, dapat mendorong kelancaran perkembangan anak. Demikian pula orang tua yang cenderung sering membanding- 
bandingkan anak yang satu dengan anak yang lain, juga bisa berpengaruh kurang baik pada perkembangan kemandirian anak. (Syafrina 2017) .

Ketiga, sistem pendidikan di sekolah. Sistem pendidikan yang ada di sekolah merupakan tem pat anak untuk dididik dalam lingkungan formal. Proses pendidikan di sekolah tanpa mengembangkan demokratisasi pendidikan, serta cenderung menekankan indoktrinasi dengan tidak memiliki argumentasi bisa menghambat pada perkembangan kemandirian. Akan tetapi kalau sebaliknya proses pendidikan di sekolah lebih menekankan pentingnya untuk penghargaan pada anak dan penciptaan kompetensi yang positif, maka itu bisa memperlancar perkembangan kemandirian belajar. Terakhir adalah sistem kehidupan di dalam masyarakat. Sistem kehidupan masyarakat yang menekankan lingkungan yang aman, begitupa pula menghargai ekspresi potensi remaja dengan berbagai macam bentuk kegiatan tanpa berlaku hierarkis, bisa merangsang dan mendorongnya kepada perkembangan kemandirian. (Syafrina 2017). Sedangkan menurut Mahmud, faktor-faktor yang bisa mempengaruhi kemandirian ada empat faktor. Pertama jenis kelamin, seperti anak laki-laki dan perem puan memiliki perbedaan. Di mana laki-laki dituntut supaya berperilaku sesuai dengan apa yang ditentukan dalam masyarakat yaitu seperti bersifat logis, agresif serta bebas terhadap anak laki-laki. Bersikap lemah lembut, ramah dan feminim terhadap anak perem puan. Kedua usia, sejak dini anak kecil berusaha mandiri, manakala seseorang mulai mengeksplorasi lingkunganya atas kemampuannya, sehingga semakin bertambah juga tingkat kemandirian seseorang ketika usianya juga bertambah. Terakhir urutan anak dalam keluarga, anak sulung biasanya lebih berorientasi pada anak dewasa, memiliki kepandaian dalam mengendalikan diri, cepat dan takut akan kegagalan, serta pasif apabila dibandingkan kepada saudaranya yang lain. Anak tengah lebih ekstrovert serta kurang mempunyai dorongan. Akan tetapi anak tengah juga mempunyai pendirian. Anak bungsu merupakan anak yang dicintai oleh orang tua. (Dimyati 1990).

Mahasiswa yang hidup di perantauan jauh dari orang tua maupun keluarga dekatnya, kemungkinan akan membuatnya mengalami tekanan psikologis. Terutama mengenai perasaan berdasarkan wawancara sebelumnya, karena menghadapi perubahan kondisi maupun situasi di tempat seseorang merantau. Padahal mahasiswa perantauan juga mempunyai kebutuhan 
dan harapan dalam dirinya. Hal-hal yang tidak biasa dilakukannya di rumah atau tempat asal mahasiswa itu tinggal, akan dilakukannya sendiri di tempat dia merantau.

Berdasarkan paparan yang dijelaskan, maka peneliti tertarik untuk meneliti tentang dinamika kemandirian terhadap mahasiswa perantauan di UIN Antarasari Banjarmasin dengan judul “Dinamika Kemandirian Mahasiswa Perantauan di UIN Antasari Banjarmasin”. Tujuan penelitian ini adalah untuk mengetahui dinamika kemandirian mahasiswa perantaun di UIN Antasari Banjarmasin. Kemudian untuk mengetahui faktor-faktor yang melatarbelakangi dinamika kemandirian mahasiswa perantaun di UIN Antasari Banjarmasin.

Dinamika dalam Kamus Besar Bahasa Indonesia (KBBI) menjelaskan ialah tenaga yang menggerakkan. Dinamis merupakan kata lain dari dinamika di dalam KBBI adalah mempunyai semangat dan tenaga, sehingga cepat bergerak dan juga mudah menyesuaikan diri dengan keadaan. (Pembinaan 1990). Adapun kata mandiri diambil dari dua istilah yang pengertiannya sering disejajarkan silih berganti, yaitu autonomy dan independence. Hal itu disebabkan perbedaannya begitu tipis. Independence mempunyai arti kebebasan, secara umum adalah menunjuk pada kemampuan seseorang yang melakukan sendiri aktivitas hidup dengan tidak menggantungkan bantuan pada orang lain. Bahwasanya dalam kamus Inggris dan Indonesia kalau istilah otonomi itu sama seperti autonomy, swastantra ialah kemampuan untuk memerintah diri sendiri, mengurus diri sendiri atau bisa juga mengatur kepentingan sendiri. (Nurhayati 2016). Menurut Monks dkk menyebutkan bahwa seseorang yang mandiri akan memperlihatkan perilaku yang eksploratif, dapat mengambil keputusan, memiliki rasa percaya diri dan juga kreatif. Demikian pula orang yang mandiri dapat bertindak kritis, tanpa takut berbuat sesuatu, memiliki kepuasan dalam mengerjakan aktifitasnya, dapat menerima realita dan bisa memanipulasi lingkungan, berinteraksi dengan sesama teman sebaya, terarah kepada tujuan dan dapat mengendalikan dirinya. Apabila tidak memiliki kemandirian, maka itu akan menghasilkan berbagai macam masalah dengan perilakunya, misalnya seperti rendah diri, pemalu, kurang mempunyai motivasi dalam dirinya, kebiasaan belajar yang kurang baik, perasaan tidak aman serta cemas. (Astuti dan Sukardi 2013). Kemandirian menurut Steinberg secara psikososial tersusun dari tiga aspek. Pertama, kemandirian emosional merupakan kemandirian yang menyatakan adanya perubahan kedekatan hubungan emosional antar orang 
lain, seperti halnya hubungan emosional dengan orang tuanya atau hubungan dengan orang dewasa lainnya atau orang yang banyak melakukan interaksi dengannya. Kedua, yaitu mandiri bertindak adalah kemampuan seseorang supaya bisa memutuskan sesuatu secara bebas dan menindaklanjutinya serta bertanggung jawab. Terakhir adalah mandiri berfikir, yaitu kebebasan untuk memaknai prinsip yang benar dan yang salah, baik dan buruk serta apa yang berguna untuk dirinya. (Nurhayati 2016).

Islam mengajarkan supaya bisa melakukan suatu pekerjaan itu dengan mandiri. Rasulullah juga memperhatikan dan membangun sifat mandiri pada anak. Terdapat juga di dalam ayat Alquran ataupun hadis memerintahkan seorang muslim untuk harus mempunyai sifat yang mandiri, tanpa mengandalkan bantuan dari orang lain. Dijelaskan juga di dalam hadis Nabi Muhammad Saw, yang diriwayatkan oleh Bukhari Muslim. Rasulullah bersabda yang artinya, bahwasanya tangan yang berada di atas lebih baik daripada tangan yang berada di bawah. (Kuswanto 2016).

Hurlock juga menyatakan bahwa supaya bisa mendapatkan tujuan dari pola sosialisasi dewasa juga diperlukan penyesuaian baru, seperti yang dialami oleh mahasiswa perantauan. Pertama, ketidakhadiran orang tua. Kedua, sistem pertemanan serta komunikasi yang berbeda dengan teman baru. Ketiga, penyesuaian terhadap norma sosialisasi warga setempat. Terakhir yaitu gaya belajar yang sulit untuk diikuti. Sebab dari itulah yang menyebabkan adanya perubahan situasi kehidupan mahasiswa yang merantau, karena menuntut usaha yang lebih besar. Hal itu dikarekan supaya mahasiswa itu mandiri dalam menghadapi perubahan lingkungan di tempat perantauan. (Lingga 2012).

Mahasiswa adalah suatu kelompok di dalam masyarakat yang memiliki status sebab ikatan dengan perguruan tinggi. (Putri dkk. 2012). Seorang mahasiswa dikategorikan pada tahap perkembangan, sebab usianya 18 sampai usia 25 tahun. Tahap ini bisa juga digolongkan masa remaja akhir sampai dengan dewasa awal, dilihat dari segi perkembangan, serta tugas perkembangan terhadap usia mahasiswa ini dalam pemantapan pendirian hidup. (Nisrina 2016). Menurut Undang -undang Republik Indonesia (UU RI) No. 20. Pada tahun 2003 yang membahas tentang Sisdiknas Bab VI, dibagian keempat pasal 19. Isinya ialah menjelaskan bahwa mahasiswa itu sebenarnya adalah sebutan kepada siswa atau murid yang telah sampai 
di jenjang pendidikan tertentu, pada masa pembelajaran di akademis. (Setyaningsih 2014). Demikian pula Naim menyebutkan bahwasanya merantau adalah tipe khusus dari migrasi dengan konotasi budaya tersendiri. Maksudnya yaitu seorang individu yang datang dari luar daerah. Meninggalkan kampung halamannya atau bisa juga disebut tanah kelahiran, yaitu untuk merantau ke kota, wilayah atau bahkan ke luar negeri, atas kemauan sendiri dengan waktu tertentu. Berbagai macam alasan orang memilih untuk melanjutkan studi di luar daerah, antara lain memperluas wawasan, memperoleh pengalaman baru dan sebagainya. (Halim dan Dariyo 2017). Menurut Irawati salah satu alasan merantau adalah supaya bisa mendapatkan pendidikan yang lebih layak sebab itu individu akan merantau untuk meraih cita-citanya. Oleh karena itu para perantau sering ditemukan di sekitaran kampus-kampus diseluruh Indonesia yang kebanyakan adalah mahasiswa. (Halim dan Dariyo 2017). Berbagai macam alasan seseorang untuk melanjutkan studinya dengan merantau, diantaranya untuk menambah pengetahuan, mendapatkan pengalaman baru dan lain-lain. (Devinta 2015)

Mahasiswa yang memilih untuk merantau, pada dasarnya mempunyai tujuan agar bisa memperoleh kualitas pendidikan yang lebih bagus, dan itu tidak didapat di daerah tempat tinggalnya. Apabila tidak mempunyai komitmen yang kuat, maka tujuan awalnya untuk memperoleh kualitas lebih baik, itu akan lebih sulit untuk bisa diperoleh. Mahasiswa yang merantau pastinya mempunyai tanggung jawab yang lebih besar atas tindakan yang dilakukannya. Hal itu dikarenakan, di lingkungan perantauan terjadi perubahan baitu itu pola hidup, kebudayaan, bahasa, keadaan di lingkungan tempat tinggalnya, begitu juga tuntutan supaya hidup mandiri. Di perantauan mahasiswa menghadapi perbedaan di berbagai aspek kehidupan, diantaranya ialah perbedaan dari pola hidup, kebiasaan, bahasa serta interaksi sosial, sehingga mahasiswa itu harus bisa menyesuaikan diri di lingkungan yang asing baginya. (Ridha 2018).

Hurlock juga menyatakan bahwa supaya bisa mendapatkan tujuan dari pola sosialisasi dewasa juga diperlukan penyesuaian baru, seperti yang dialami oleh mahasiswa perantauan. Pertama, ketidakhadiran orang tua. Kedua, sistem pertemanan serta komunikasi yang berbeda dengan teman baru. Ketiga, penyesuaian terhadap norma sosialisasi warga setem pat. Terakhir yaitu gaya belajar yang sulit untuk diikuti. Sebab dari itulah yang menyebabkan adanya 
perubahan situasi kehidupan mahasiswa yang merantau, karena menuntut usaha yang lebih besar. Hal itu dikarekan supaya mahasiswa itu mandiri dalam menghadapi perubahan lingkungan di tempat perantauan. (Lingga 2012)

\section{Metode}

Jenis penelitian ini adalah penelitian deskriptif kualitatif. Pemilihan subjek menggunakan teknik purposive sampling, yaitu berdasarkan ciri dimiliki subjek yang dipilih, seperti mahasiswa yang meninggalkan kampung halamannya untuk merantau. Jarak tempuh yang dilaluinya kurang lebih sekitar 10 jam perjalanan. Objek penelitian ini adalah dinamika kemandirian, subjeknya adalah mahasiswa perantauan UIN Antasari Banjarmasin sebanyak 5 orang. Teknik pengumpulan data menggunakan wawancara dan observasi.

\section{H a s i 1}

Berdasarkan hasil penelitian yang didapat oleh peneliti, bahwasanya mahasiswa perantauan di UIN Antasari Banjarmasin telah mengalami dinamika kemandirian. Seperti yang dialami subjek ES merasa sulit hidup di perantauan karena pertama kali baginya jauh dari keluarganya. Terkadang menangis karena rindu dengan keluarganya. Ingin melakukan sesuatu sendirian dan harus pintar dalam mengatur keuangan sendiri. Tapi seiring berjalannya waktu, membuat subjek ES mulai terbiasa dengan kehidupan di perantauan. Menjalani kehidupan di perantauan membuat subjek ES bersabar dan bersikap mandiri. Hal itu dikarenakan, subjek ES berpikir tidak selamanya memerlukan bantuan orang lain, begitu juga orang lainpun tidak selamanya bisa membantunya. Dengan pemikiran seperti itu membuat subjek ES membiasakan diri untuk tidak meminta bantuan dari orang lain dan bersikap mandiri dalam menjalani kehidupan di perantauan. Sama halnya yang dialami subjek FA, merasa sulit hidup di perantauan karena mengatur keuangan sendiri. Tapi dari kecil subjek FA sudah diajarkan untuk melakukan sesuatu sendiri dan mengurus diri sendiri. Sehingga setelah kurun waktu berlalu, subjek FA mulai terbiasa mengatur keuangannya sendiri, bahkan belajar untuk mencari penghasilan sendiri di perantauan. Begitu juga dinamika kemandirian yang dialami oleh subjek 
HT. Awalnya subjek HT memang suka dengan dunia baru, pengalaman baru dan suasana baru. Jadi setelah berada di perantauan subjek HT merasa lebih bersemangat. Walaupun terkadang rindu sama keluarganya dan ingin pulang ke kampung halamnnya. Tapi menurut subjek HT itu merupakan tantangan bagi dirinya yang jauh dari keluarganya. Subjek HT juga memang menyukai hal-hal baru. Dari hal itu semua membuat subjek HT bisa menjalani kehidupan di perantauan. Demikian pula dinamika kemandirian yang dialami oleh subjek VD. Dulu sebelum merantau ke Banjarmasin. Subjek VD sudah pernah merantau waktu SMK. Setelah merantau ke Banjarmasin subjek VD bekerja selama dua tahun. Setelah itu baru kuliah dan bekerja paruh waktu. Di tempat bekerja, Subjek VD butuh beberapa waktu dalam menyesuaikan diri, sebab berada di bawah tekanan atasan. Sehingga itu membuat subjek VD merasa kesulitan di perantauan. Tapi subjek VD mengatakan kalau waktu kecil sudah diajarkan oleh orang tuanya untuk berusaha sendiri dan mendapat penghasilan sendiri. Dari pengalaman waktu kecil dan pengalaman merantau sebelumnya, membuat subjek VD mengamati lingkungan di sekitar dan memahami kondisinya. Sehingga membuatnya mudah berbaur dengan lingkungannya sekarang di Banjarmasin. Seterusnya seperti halnya yang dialami subjek NY. Subjek NY merasa hidup di perantaun itu menyedihkan, karena awalnya tidak tau bahwa kehidupan di Banjarmasin memiliki kriminalitas yang tinggi, sehingga membuat subjek NY merasa takut. Begitu juga pergaulannya bebas dan itu hal biasa di kota-kota besar. subjek NY juga merasa bahwa hidup di perantaun perasaan campur aduk yaitu ada sedih karena jauh dari orang tua, merasa khawatir karena tinggal di kota besar dan juga merasa senang karena bisa belajar halhal baru. Ibu subjek NY sudah meninggal dan kakak-kakaknya kebanyakan laki-laki. Di perantauan membuat subjek NY lebih bersikap dewasa dalam menghadapi masalah. Apalagi Di Banjarmasin subjek NY tinggal bersama adik bungsunya, sehingga membuat subjek NY merasa bertanggung jawab dalam membimbing adiknya.

Seperti yang dialami oleh para subjek di atas. Hal itu disebabkan peluang untuk bergantung pada orang lain sangatlah minim dan dalam memenuhi kebutuhan hidupnya, harus dilakukanya sendiri. Hurlock uga menyatakan bahwa supaya bisa mendapatkan tujuan dari pola sosialisasi dewasa juga diperlukan penyesuaian baru, seperti yang dialami oleh mahasiswa perantauan. Pertama, ketidakhadiran orang tua. Kedua, sistem pertemanan serta 
komunikasi yang berbeda dengan teman baru. Ketiga, penyesuaian terhadap norma sosialisasi warga setempat. Terakhir yaitu gaya belajar yang sulit untuk diikuti. Sebab dari itulah yang menyebabkan adanya perubahan situasi kehidupan mahasiswa yang merantau, karena menuntut usaha yang lebih besar. Hal itu dikarekan supaya mahasiswa itu mandiri dalam menghadapi perubahan lingkungan di tempat perantauan.

Hidup di perantauan pastinya para subjek mengalami berbagai masalah. Seperti yang dialami oleh subjek ES, HT, FA, VD dan NY. Sebagian dari subjek ada kosnya yang kemalingan sehingga barang-barang yang berharga banyak yang hilang. Ada juga yang kesulitan dengan jadwal kuliah dan jadwal kerja, karena bentrokan. Begitu juga dengan masalah pekerjaan dan tugas-tugas di perkuliahan. Ketika mendapat berbagai masalah, sebagian dari para subjek ada yang merasakan kaget, sedih dan stres akan hal tersebut. Tapi para subjek mengalihkannya dengan melakukan kegiatan lain seperti curhat, berkumpul bersama teman yang lain, nonton, shalat dan berdoa. Bisa juga langsung para subjek selesaikan masalah tersebut. Menurut para subjek, supaya tidak menambah beban pikirannya. Hal itu dikarenakan, para subjek tidak ingin membuat keluarganya khawatir dengan keadaanya di perantauan dan juga tidak ingin terlalu bergantung dengan orang lain. Ini sama halnya seperti yang dijelaskan oleh Havighurst, bahwa bentuk kemandirian secara intelektual, adalah merupakan kemampuan untuk mengatasi berbagai masalah yang dihadapi. Begitu juga seperti pendapat Steinberg yang menjelaskan tentang kemandirian secara psikososial tersusun atas beberapa aspek, diantaranya ialah aspek kemandirian emosional. Yang dimaksud dengan kemandirian secara emosional adalah kemandirian yang menyatakan perubahan kedekatan hubungan emosional antar individu. Seperti hubungan emosional dengan orang tuanya atau dengan orang dewasa lainnya yang banyak melakukan interaksi denganya. Begitu juga dengan kemandirian bertindak. Kemandirian bertindak merupakan kemampuan untuk membuat keputusan secara bebas dan menindaklanjutinya serta bertanggung jawab.

Dari hasil penelitian yang didapat oleh peneliti, bahwasanya para subjek juga memiliki pendirian untuk bisa mengatur keuangannya sendiri. Seperti subjek ES tidak bekerja karena tidak ingin membuat orang tuanya khawatir dengan keadaanya di perantauan. Tapi itu membuat subjek ES pintar dalam mengatur keuangannya sendiri. Begitu juga subjek HT, VD, 
FA dan NY di sela-sela kuliah, para subjek juga bekerja. Untuk memenuhi biaya yang dibutuhkan di tempat perantauan. Sama seperti pendapat Havighurst, yang menjelaskan kalau itu merupakan bentuk dari kemandirian ekonomi. Maksud dari kemandirian ekonomi adalah kemampuan mengatur ekonomi sendiri dan tidak tergantungnya pada kebutuhan ekonomi orang lain. (Desmita 2014). Masrun juga mengatakan bahwa itu merupakan aspek bebas. Bebas maksudnya ialah yang ditujukan dengan tindakan yang dilakukan atas kehendak atau keinginan sendiri, tanpa bergantung dengan orang lain. (Octavia 2010).

Dari hasil di atas, dapatlah dikatakan bahwasanya para subjek telah mengalami dinamika kemandirian, karena di perantauan telah terjadi perubahan. Hidup di perantauan para subjek jauh dari keluarga dan tinggal di lingkungan yang baru bagi dirinya, sehingga membutuhkan proses untuk bisa mandiri dalam mengurus dirinya sendiri, baik itu kebutuhanya dan masalah yang dihadapi di perantauan. Hidup di perantauan jauh dari orang tua merupakan pemicu yang membuat para subjek untuk bersikap mandiri.

Adapun faktor-faktor yang mempengaruhi dinamika kemandirian berdasarkan hasil wawancara yang telah peneliti lakukan dengan kelima subjek penelitian. Para subjek menyatakan ketika menjalani kehidupan di perantauan yang membuatnya untuk hidup mandiri ialah, karena didikan orang tua dari kecil yang membuat para subjek memiliki pengalaman untuk belajar mandiri dalam menjalani kehidupan di perantauan. Hal ini selaras dengan pendapat Ali dan Asrori yang mengatakan, bahwa faktor yang mempengaruhi kemandirian diantaranya adalah pola asuh orang tua. Cara orang tua mengasuh atau mendidik anak akan mempengaruhi perkembangan kemandirian anak remajanya. Orang tua yang terlalu banyak melarang atau mengeluarkan kata "jangan" kepada anak tanpa disertai dengan penjelasan yang rasioanal akan menghambat perkembangan kemandirian anak. Sebaliknya, orang tua yang menciptakan suasana aman dalam interaksi keluarganya akan dapat mendorong kelancaran perkembangan anak. Begitu pula orang tua yang cenderung sering membanding-bandingkan anak yang satu dengan yang lainnya juga dapat berpengaruh kurang baik terhadap perkembangan kemandirian anak. (Syafrina 2017).

Begitu pula Mahmud menyatakan, bahwa faktor yang bisa mem pengaruhi kemandirian ialah urutan anak dalam keluarga. Anak sulung biasanya lebih berorientasi pada anak dewasa, 
pandai mengendalikan diri, cepat, takut gagal serta pasif jika dibandingkan dengan saudarasaudaranya. Anak tengah lebih ekstrovert serta kurang mempunyai dorongan. Akan tetapi anak itu memiliki pendirian. Sedangkan anak bungsu adalah anak yang disayang orang tua. (Dimyati 1990). Ini sama halnya dengan hasil penelitian yang didapat oleh peneliti terhadap subjek HT, VD dan NY. Para subjek memiliki pendirian untuk mengurangi beban orang tuanya. Para subjek bekerja untuk memenuhi biaya yang dibutuhkan sendiri di perantauan. Hal itu dikarenakan para subjek merasa bahwa saudaranya juga membutuhkan biaya dari orang tua.

Menurut Mahmud faktor usia juga berpengaruh dalam kemandirian. Sejak dini anak kecil berusaha mandiri manakala anak itu mulai mengeksplorasi lingkunganya atas dasar kemampuannya sendiri, sehingga semakin bertambah tingkat kemandirian seseorang ketika usianya bertambah. (Dimyati 1990). Seperti halnya yang dialami oleh subjek FA, karena dari kecil sudah di tinggal oleh orang tuanya sampai beberapa hari, sehingga yang mengurus kebutuhannya ialah dirinya sendiri. Jadi ketika menjalani pendidikan yang lebih tinggi di tempat perantauan, subjek FA sudah terbiasa terpisah dengan orang tuannya dan mengurus kehidupannya sendiri di perantauan.

Menurut Ali dan Asrori, faktor sistem pendidikan di sekolah juga berpengaruh terhadap kemandirian. Sistem pendidikan di sekolah merupakan sistem pendidikan yang ada di sekolah tempat anak dididik dalam lingkungan formal. Proses pendidikan di sekolah yang lebih menekankan pentingnya penghargaan terhadap anak serta penciptaan kompetensi positif akan memperlancar perkembangan kemandirian belajar. (Syafrina 2017).

Faktor di atas sama halnya yang dialami oleh subjek NY. Dulu waktu di pondok subjek NY sudah diajarkan apa yang buruk dan yang baik. Waktu di pondok juga diajarkan bagaimana harus menjaga diri dan bagaimana bersikap terhadap lingkungan sekitar. Hal itu dikarenakan subjek sudah lama hidup diperantauan jauh dari orang tua, sehingga membuatnya lebih mudah dalam menyesuaikan diri terhadap lingkungan baru, baik itu dalam hal mengatasi masalah sendiri, mengurus diri sendiri dalam menjalani kehidupan di perantauan.

\section{Kesimpulan}


Dapat disimpulkan bahwa mahasiswa perantauan mengalami dinamika kemandirian. Mahasiswa yang hidup di perantauan jauh dari orang tua maupun keluarga dekatnya, kemungkinan akan membuatnya mengalami tekanan psikologis. Terutama mengenai perasaan, seperti sedih, stress, takut, kaget dan bingung. Hal itu disebabkan, seorang mahasiswa di hadapi berbagai macam situasi dan kondisi dalam menjalani kehidupan di perantauan. Seperti mengatur perekonomiannya sendiri, menyelesaikan masalah sendiri, tanpa bergantung dengan orang lain. Sebab dari itulah yang membuat mahasiswa perantauan membutuhkan proses dan waktu, untuk menjadi mahasiswa yang mandiri dalam menjalani kehidupan di perantauan.

Adapun faktor-faktor yang mempengaruhi kemandirian pada mahasiswa perantauan. Diantaranya seperti pola asuh orang tua. Hal itu dikarenakan didikan orang tua dari kecil yang membuat mahasiswa perantauan memiliki pengalaman untuk belajar mandiri dalam menjalani kehidupannya di perantauan. Begitu pula faktor urutan anak dalam keluarga. Anak sulung biasanya lebih berorientasi pada anak dewasa, pandai mengendalikan diri, cepat, takut gagal serta pasif jika dibandingkan dengan saudara-saudaranya. Anak tengah lebih ekstrovert serta kurang mempunyai dorongan. Akan tetapi mereka memiliki pendirian. Sedangkan anak bungsu adalah anak yang disayang orang tua. begitu juga dengan usia. Sejak dini anak kecil berusaha mandiri manakala ia mulai mengeksplorasi lingkunganya atas dasar kemampuannya sendiri, sehingga semakin bertambah tingkat kemandirian seseorang ketika usianya bertambah. Dan yang terakhir adalah sistem pendidikan di sekolah. Sistem pendidikan di sekolah merupakan sistem pendidikan yang ada di sekolah tempat anak dididik dalam lingkungan formal. Proses pendidikan di sekolah yang lebih menekankan pentingnya penghargaan terhadap anak serta penciptaan kompetensi positif akan memperlancar perkembangan kemandirian belajar.

\section{Saran}

Untuk kajian penelitian ini terdiri dari dimensi kemandirian seperti aspek kemandirian dan faktor kemandirian. Jadi Bagi peneliti selanjutnya yang ingin mengkaji penelitian serupa, diharapkan melakukan penelitian lanjutan dengan mempertimbangkan dimensi-dimensi di 
kemandirian, seperti bentuk-bentuk kemandirian dan ciri-ciri kemandirian. Bisa juga dengan menambah jumlah sampel yang lebih besar lagi, agar hasil dari penelitian dapat digenaralisasi

\section{Referensi}

Al-Qurthubi, Imam. 2009. Tafsir Al-Qur'an(9). Terj. Muhyiddin Mas Rida dan M. Rana Mengala. Mukhlis B Mukti. Jakarta: Pustaka Azzam.

Astuti, Sri, dan Thomas Sukardi. 2013. "Faktor-faktor yang mempengaruhi kemandirian untuk berwirausaha pada siswa SMK." Jurnal Pendidikan Vokasi 3 (3). https://doi.org/10.21831/jpv.v3i3.1847.

Desmita. 2014. Psikologi Perkembangan Peserta Didik. Bandung: PT Remaja Rosdakarya.

Devinta, Marshellena. 2015. "Fenomena Cultural Shock (Geger Budaya) pada Mahasiswa Perantauan di Yogyakarta," 15.

Dimyati, Mahud. 1990. Psikologi Pendidikan Suatu Pendekatan Terapan. Yogyakarta: BPPE.

Halim, Cindy Frencya, dan Agoes Dariyo. 2017. “Hubungan Psychological Well-Being dengan Loneliness pada Mahasiswa yang Merantau." Journal Psikogenesis 4 (2): 170. https://doi.org/10.24854/jps.v4i2.344.

Kuswanto, Cahniyo Wijaya. 2016. "Menumbuhkan Kemandirian Anak Usia Dini Melalui Bermain." Jurnal Ilmiah Pendidikan Islam Anak Usia Dini 1 (2).

Lingga, Ruth Widya W. L. dan Josetta M. R. Tuapattinaja. 2012. “Gambaran Virtue Mahasiswa Perantau." Predicara 1 (2): 11.

Nisrina, Ghina Elzanadia. 2016. "Perbedaan Strategi Coping Stress Pada Mahasiswa Organisasi Dan Non Organisasi Di Universitas Islam Negeri Maulana Malik Ibrahim Malang." Malang: Universitas Islam Negeri Maulana Malik Ibrahim Malang.

Nurhayati, Eti. 2016. Psikologi Pendidikan Inovatif. Yogyakarta: Pustaka Belajar.

Octavia, Putri Primasari. 2010. "Hubungan Antara Konsep Diri Dengan Kemandirian Pada Mahasiswa Bimbingan dan Konseling Angkatan 2005 dan 2006 UNNES." Semarang.

Pembinaan, Tim Penyusun Kamus Besar Bahasa Indonesia/Tim Penyusun Kamus Pusat dan Pengembangan Bahasa. 1990. Kamus Besar Bahasa Indonesia. Jakarta: Balai Pustaka.

Putri, Anggia, Meita Santi Budiani, S Psi, dan M Psi. 2012. "Pengaruh Kelelahan Emosional Terhadap Perilaku Belajar pada Mahasiswa yang Bekerja," 20.

Ridha, Andi Ahmad. 2018. “Task Commitment pada Mahasiswa Suku Bugis yang Merantau." Jurnal Psikologi 45 (1). https://doi.org/10.22146/jpsi.31094.

Setyaningsih, Ira. 2014. "Analisis Faktor Penghambat Keberhasilan Mahasiswa Menjadi Entrepreneur," 7.

Syafrina, Alfiati. 2017. “Analisis Kemandirian Siswa dalam Proses Pembelajaran di Kelas III SD Negeri Banda Aceh” 1: 12. 


\begin{tabular}{|l|l|l|l|l|}
\hline Submit & Review & Revisi & Diterima & Publish \\
\hline $01-09-2020$ & - & - & $30-03-2021$ & $22-04-2021$ \\
\hline
\end{tabular}

Nadia Fauzia, Asmaran dan Shanty Komalasari

Program Studi Psikologi Islam

Fakultas Ushuluddin dan Humaniora

Universitas Islam Negeri (UIN) Antasari Banjarmasin

Email : banjarsenju@gmail.com 